\title{
Knoellia flava sp. nov., isolated from pig manure
}

\author{
Correspondence \\ Gejiao Wang \\ gejiaow@yahoo.com.cn or \\ gejiao@mail.hzau.edu.cn
}

\author{
Xiang Yu, Yan Du and Gejiao Wang
}

State Key Laboratory of Agricultural Microbiology, College of Life Science and Technology, Huazhong Agricultural University, Wuhan 430070, PR China

\begin{abstract}
A Gram-positive, aerobic, non-spore-forming actinobacterial strain, designated strain $\mathrm{TL1}^{\top}$, was isolated from pig manure in Wuhan, China. The cell wall peptidoglycan contained meso-diaminopimelic acid. The major polar lipids were phosphatidylethanolamine, phosphatidylinositol and diphosphatidylglycerol. The predominant menaquinone was $\mathrm{MK}-8\left(\mathrm{H}_{4}\right)$. The major fatty acids $(>10 \%)$ were iso- $C_{16: 0}$, iso- $C_{15: 0}$ and $C_{17: 1} \omega 8 c$. The genomic DNA $\mathrm{G}+\mathrm{C}$ content was 70.9 mol\%. Phylogenetic analysis based on 16S rRNA gene sequences indicated that strain $\mathrm{TL}_{1}{ }^{\top}$ was most closely related to the type strains of Knoellia sinensis (98.5\%), Knoellia subterranea (98.2\%) and Knoellia aerolata (96.9\%). DNA-DNA relatedness values of strain $\mathrm{TL}^{\top}{ }^{\top}$ with the type strains of $K$. sinensis and $K$. subterranea were 27.3 and $34.0 \%$, respectively. Comparison of phenotypic, chemotaxonomic and phylogenetic characteristics among strain $\mathrm{TL}_{1}^{\top}$ and related organisms revealed that the isolate represents a novel species of the genus Knoellia, for which the name Knoellia flava sp. nov. is proposed; the type strain is $\operatorname{TL}^{\top}{ }^{\top}\left(=\right.$ CGMCC $1.10749^{\top}=$ KCTC $\left.19810^{\top}\right)$.
\end{abstract}

The family Intrasporangiaceae was first described by Stackebrandt et al. (1997), and later emended by Stackebrandt \& Schumann (2000) and Zhi et al. (2009). Currently, it contains 19 genera with validly published names, which have been divided into three groups based on the diagnostic diamino acids in the cell-wall peptidoglycan [eight genera with meso-diaminopimelic acid (DAP), seven with LL-DAP and four with L-ornithine] (Lee, 2006; Wang et al., 2009). The genus Knoellia belongs to the first group and was proposed by Groth et al. (2002) based on the studies of two species, Knoellia sinensis and Knoellia subterranea, isolated from soil in Reed Flute Cave, Guilin, China. Weon et al. (2007) reported another species, Knoellia aerolata, which was isolated from air. At the time of writing, the genus Knoellia contained only three species, with the following typical characteristics: Gram-positive, aerobic, non-spore-forming, irregular rods or cocci, containing $\mathrm{MK}-8\left(\mathrm{H}_{4}\right)$ as the major menaquinone and meso-DAP in the cell-wall peptidoglycan (Groth et al., 2002; Weon et al., 2007).

During the course of an investigation of cultivable bacteria from pig manure, bacteria were isolated from a pig manure sample collected from a hoggery in Huazhong Agricultural University $\left(114^{\circ} 35^{\prime} \mathrm{E} 30^{\circ} 48^{\prime} \mathrm{N}\right)$, Wuhan, central PR China. For isolation, $10 \mathrm{~g}$ sample was mixed thoroughly

Abbreviations: DAP, diaminopimelic acid; DPG, diphosphatidylglycerol; $\mathrm{PE}$, phosphatidylethanolamine; PI, phosphatidylinositol; PL, phospholipid; PG, phosphatidylglycerol.

The GenBank/EMBL/DDBJ accession number for the $16 \mathrm{~S}$ rRNA gene sequence of strain $\mathrm{TL}^{\top}{ }^{\top}$ is HQ401007.

Four supplementary figures are available with the online version of this paper. with $90 \mathrm{ml} 0.85 \% \mathrm{NaCl}$ solution, plated onto $10 \%$ tryptic soy broth $(0.1 \times$ TSB; Difco $)$ agar plates and incubated at $28{ }^{\circ} \mathrm{C}$ for 1 week. A total of seven bacterial strains were isolated and pre-identified as Bacillus (three strains), Klebsiella (two strains), Knoellia (one strain, $\mathrm{TL}^{\mathrm{T}}$ ) and Paenibacillus (one strain) based on partial 16S rRNA gene sequence analysis. Here, strain TL1 ${ }^{\mathrm{T}}$ was studied using a polyphasic approach in order to determine its taxonomic position.

Strain $\mathrm{TL} 1^{\mathrm{T}}$ was routinely cultured on R agar (g per $100 \mathrm{ml}$ : bacto peptone, 1 ; yeast extract, 0.5 ; Casamino acids, 0.5 ; beef extract, 0.2 ; malt extract, 0.5 ; glycerol, 0.2; $\mathrm{MgSO}_{4} \cdot 7 \mathrm{H}_{2} \mathrm{O}, 0.1$; Tween $\left.80,0.005\right)$ at $28{ }^{\circ} \mathrm{C}$ for 3 days. Phenotypic characterizations were performed following the recommended minimal standards for describing new genera and species of the suborder Micrococcineae (Schumann et al., 2009). Growth was tested at 0, 4, 15, 20, 28, 37 and $42{ }^{\circ} \mathrm{C}$. Colony morphologies were observed on $\mathrm{R}$ and R2A (g per $100 \mathrm{ml}$ : yeast extract, 0.05 ; proteose peptone, 0.05; Casamino acids, 0.05; glucose, 0.05; soluble starch, 0.05 ; sodium pyruvate, 0.03 ; dipotassium phosphate, 0.03; magnesium sulphate, 0.005) plates. Cell morphologies were observed by light and scanning electron microscopy after various incubation times. $\mathrm{NaCl}$ tolerance was determined with $0-6 \%(\mathrm{w} / \mathrm{v}) \mathrm{NaCl}$ in $\mathrm{R}$ medium at $28{ }^{\circ} \mathrm{C}$. The $\mathrm{pH}$ range $(4-10)$ for growth was determined at $28^{\circ} \mathrm{C}$. Anaerobic growth was determined by incubation in an anaerobic chamber (Mitsubishi Gas Chemical Co.) at $28{ }^{\circ} \mathrm{C}$. Gram staining was determined using the method described by Dussault (1955) and tested by the $\mathrm{KOH}$ lysis method (Ryu, 1938). Hydrolysis of casein, aesculin, gelatin, 
L-tyrosine, urea, starch, Tween 80 , Tween 20, chitin from crab shells and carboxymethyl-cellulose was performed as described by Cowan \& Steel (1965). Nitrate reduction was tested as described by Lányí (1987). Methyl red and VogesProskauer tests, and determination of $\mathrm{H}_{2} \mathrm{~S}$ and indole production, and catalase and oxidase activities were carried out as described by Smibert \& Krieg (1994). Antibiotic susceptibility tests were performed by spreading bacterial suspensions on culture plates and applying filter-paper discs containing different antibiotics. Other physiological/ biochemical properties and enzyme activities were examined using API 20NE, ID 32GN and API ZYM systems (bioMérieux) according to the manufacturer's instructions.

A nearly completed 16S rRNA gene sequence was amplified as described by Zou \& Wang (2010) and compared with sequences available in NCBI/GenBank using BLASTN searches. The $16 \mathrm{~S}$ rRNA gene sequence of strain TL1 ${ }^{\mathrm{T}}$ was aligned with the corresponding sequences of members of the family Intrasporangiaceae using CLUSTAL $\mathrm{w}$ software (Thompson et al., 1994). Phylogenetic analysis was performed using MEGA4.0 (Tamura et al., 2007) and the PHYML online web server (Guindon et al., 2005). Distances and clustering were determined using the neighbour-joining (Saitou \& Nei, 1987), maximum-parsimony (Fitch, 1971) and maximumlikelihood (Felsenstein, 1981) methods with bootstrap analyses based on 1000 replications. DNA-DNA hybridization was performed by the thermal denaturation and renaturation method (Huß et al., 1983).

Polar lipids were extracted and analysed as described by Tindall (1990) and Ventosa et al. (1993). Peptidoglycan was analysed by the method of Schleifer \& Kandler (1972). The DNA G $+\mathrm{C}$ content of strain $\mathrm{TL1}^{\mathrm{T}}$ was determined by HPLC according to the method of Mesbah et al. (1989). For whole-cell fatty acid analysis, strain $\mathrm{TL1}^{\mathrm{T}}$ and three reference strains were grown on R2A agar at $28{ }^{\circ} \mathrm{C}$ for 3 days and analysed by GC (Hewlett Packard 6890) according to the standard protocol of the Sherlock Microbial Identification System (MIDI Sherlock version 4.5; MIDI database TSBA40 4.10) (Kroppenstedt, 1985; Sasser, 1990). Respiratory quinones were extracted and identified by HPLC as described by Xie \& Yokota (2003).

Cells of strain $\mathrm{TL1}^{\mathrm{T}}$ were Gram-positive, non-motile, nonspore-forming, irregular rods and cocci. Colonies were circular, smooth and convex on $\mathrm{R}$ medium. Colonies of strain $\mathrm{TL1}^{\mathrm{T}}$ were light yellow on R agar and yellow on R2A agar, whereas colonies of the other Knoellia species were all creamy white on both R agar and R2A agar plates (see Supplementary Fig. S1, available in IJSEM Online). As observed in the three reference strains, strain $\mathrm{TL1}^{\mathrm{T}}$ exhibited a rod-coccus growth cycle; cells were mostly irregular rod shapes after incubation for 1 day and mostly

Table 1. Differential phenotypic characteristics of strain $\mathrm{TL}^{\top}$ and the type strains of members of the genus Knoellia

Strains: 1 , TL1 ${ }^{\mathrm{T}}$; 2, K. sinensis KCTC $19936^{\mathrm{T}}$; 3, K. subterranea KCTC $19937^{\mathrm{T}}$; 4, K. aerolata DSM $18566^{\mathrm{T}}$. All data are from this study. +, Positive; -, negative; $w$, weak reaction.

\begin{tabular}{|c|c|c|c|c|}
\hline Characteristic & 1 & 2 & 3 & 4 \\
\hline \multicolumn{5}{|l|}{ Colour on: } \\
\hline R agar & Light yellow & Creamy white & Creamy white & Creamy white \\
\hline R2A agar & Yellow & Creamy white & Creamy white & Creamy white \\
\hline $\mathrm{NaCl}$ range $(\%, w / v)$ & $0-5.0$ & $0-4.0$ & $0-4.0$ & $0-2.0$ \\
\hline Growth at $37{ }^{\circ} \mathrm{C}$ & + & - & + & + \\
\hline \multicolumn{5}{|l|}{ Hydrolysis of: } \\
\hline Casein & + & + & + & - \\
\hline Tyrosine & - & + & + & - \\
\hline \multicolumn{5}{|c|}{ API 20NE/API 32GN results: } \\
\hline Arginine dihydrolase & $\mathrm{W}$ & - & - & - \\
\hline D-Mannose & + & - & + & + \\
\hline D-Mannitol & + & - & + & + \\
\hline$N$-Acetylglucosamine & - & - & + & + \\
\hline Potassium gluconate & - & - & - & + \\
\hline Adipic acid & - & $\mathrm{w}$ & - & - \\
\hline Malic acid & + & - & + & - \\
\hline D-Ribose & - & - & + & - \\
\hline Inositol & - & - & - & + \\
\hline Lactic acid & + & w & + & - \\
\hline L-Alanine & + & - & + & + \\
\hline L-Serine & + & + & + & - \\
\hline D-Sorbitol & + & - & + & + \\
\hline L-Histidine & + & + & + & - \\
\hline
\end{tabular}


cocci after incubation for 3 days (Supplementary Fig. S2, available in IJSEM Online). Detailed results of the morphological, physiological and biochemical characteristics are given in the species description. Strain $\mathrm{TL1}^{\mathrm{T}}$ showed some characteristics that were typical of the other Knoellia species but many differences were also observed. The main phenotypic differences between strain $\mathrm{TL1}^{\mathrm{T}}$ and type strains of the genus Knoellia are shown in Table 1.

The 1484 bp 16S rRNA gene sequence of strain $\mathrm{TL1}^{\mathrm{T}}$ was similar to those of members of the Intrasporangiaceae, particularly to those of the genus Knoellia. Strain $\mathrm{TL} 1^{\mathrm{T}}$ had highest 16S rRNA gene sequence similarities to $K$. sinensis DSM $12331^{\mathrm{T}}(98.5 \%)$, K. subterranea DSM $12332^{\mathrm{T}}(98.2 \%)$, K. aerolata $5317 \mathrm{~S}-21^{\mathrm{T}}(96.9 \%)$, Janibacter anophelis CCUG $49715^{\mathrm{T}}(97.1 \%)$ and Janibacter melonis DSM $16063^{\mathrm{T}}(97.1 \%)$. A phylogenetic tree constructed using the neighbour-joining algorithm revealed that strain $\mathrm{TL1}^{\mathrm{T}}$ clustered with the three species of the genus Knoellia and was separated from members of the genus Janibacter and other genera of the family Intrasporangiaceae (Fig. 1). Analyses using the maximumparsimony and the maximum-likelihood algorithms showed similar results (Supplementary Fig. S3a, b, available in IJSEM Online). DNA-DNA relatedness values of strain $\mathrm{TL}_{1}^{\mathrm{T}}$ with the type strains of K. sinensis and K. subterranea were 27.3 and $34.0 \%$, respectively. These values were significantly lower than the threshold value $(70 \%)$ suggested for the delineation of novel species (Stackebrandt \& Goebel, 1994).

The major menaquinone of strain $\mathrm{TL1}^{\mathrm{T}}$ was $\mathrm{MK}-8\left(\mathrm{H}_{4}\right)$. The cell wall peptidoglycan contained meso-DAP as the diagnostic di-amino acid. These two characters were identical to those reported for the three species within the genus Knoellia (Groth et al., 2002; Weon et al., 2007). The polar lipid profile of strain $\mathrm{TL1}^{\mathrm{T}}$ included PE, PI, DPG and a small amount of unknown phospholipid(s) (PL) (Supplementary Fig. S4, available in IJSEM Online). The other three species of the genus Knoellia also contained PE, PI and DPG as the major polar lipids; in addition, they all possessed very small amounts of phosphatidylglycerol (PG) (Groth et al., 2002; Weon et al., 2007), which was not detected in strain $\mathrm{TL1}^{\mathrm{T}}$. The DNA G $+\mathrm{C}$ content of strain $\mathrm{TL}^{\mathrm{T}}{ }^{\mathrm{T}}$ was $70.9 \mathrm{~mol} \%$. Major cellular fatty acids $(>10 \%)$ were iso- $\mathrm{C}_{16: 0}(33.6 \%)$, iso- $\mathrm{C}_{15: 0}(15.9 \%)$ and $\mathrm{C}_{17: 1} \omega 8 c$ $(11.5 \%)$ on R2A medium (details are shown in Table 2), which were very similar to those observed in strains of the genus Knoellia (Weon et al., 2007). Although strain TL1 ${ }^{\mathrm{T}}$ exhibited $97.1 \% 16 \mathrm{~S}$ rRNA gene sequence similarities to strains of the two Janibacter species studied, phylogenetic analyses showed that they belonged to two separate clusters. In addition, the major polar lipids and fatty acid contents clearly distinguished strain $\mathrm{TL} 1^{\mathrm{T}}$ from members of the genus Janibacter. Members of the genus Knoellia contain $\mathrm{PE}$ as a major polar lipid and iso- $\mathrm{C}_{15: 0}$ as a major fatty acid, whereas species of the genus Janibacter lacked PE and had a much lower amount of iso- $\mathrm{C}_{15: 0}$ (Martin et al., 1997; Groth et al., 2002; Lang et al., 2003; Yoon et al., 2004; Kämpfer et al., 2006; Kageyama et al., 2007; Weon et al., 2007; Shivaji et al., 2009) (Table 2). There were differences in the proportions of some fatty acids when the strains were grown on R2A and TSB media. Groth et al. (2002)

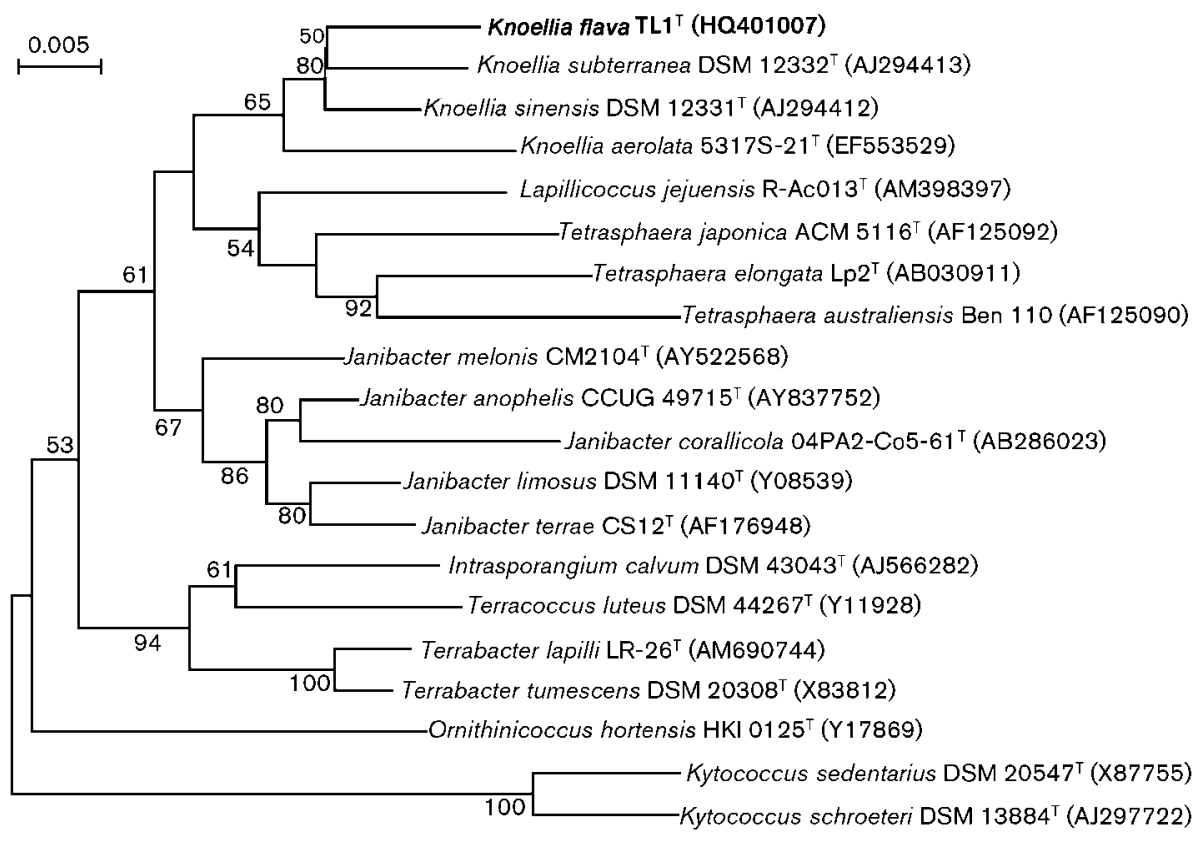

Fig. 1. A neighbour-joining tree based on 16S rRNA gene sequences showing the phylogenetic position of strain $\operatorname{TL}^{\top}$ among closely related strains. Bootstrap values $(\geqslant 50 \%)$ based on 1000 replications are shown at branch nodes. Bar, 0.005 substitutions per nucleotide. 
Table 2. Chemotaxonomic characteristics of strain $\mathrm{TL}^{\top}{ }^{\top}$ and the type strains of members of the genera Knoellia and Janibacter

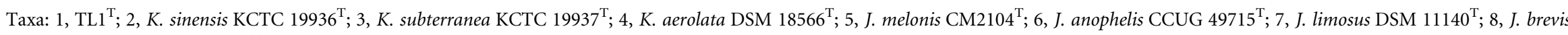

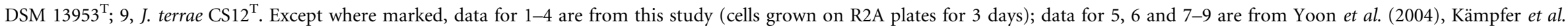
(2006) and Lang et al. (2003), respectively.,$-<1 \%$ or not detected; NA, not available.

\begin{tabular}{|c|c|c|c|c|c|c|c|c|c|}
\hline Characteristic & 1 & 2 & 3 & 4 & 5 & 6 & 7 & 8 & 9 \\
\hline \multicolumn{10}{|l|}{ Fatty acid: } \\
\hline iso- $\mathrm{C}_{14: 0}$ & 8.3 & 6.5 & 10.9 & 1.7 & 2.8 & 4.7 & - & - & 1.1 \\
\hline $\mathrm{C}_{15: 0}$ & 3.1 & - & 1.7 & - & 12.1 & 3.3 & - & - & 2.4 \\
\hline iso- $\mathrm{C}_{15: 0}$ & 15.9 & 8.7 & 11.7 & 19.9 & 5.1 & 4.4 & - & 3.72 & - \\
\hline anteiso- $\mathrm{C}_{15: 0}$ & - & - & 3.2 & 5.6 & 1.2 & - & - & - & - \\
\hline $\mathrm{C}_{16: 0}$ & 1.2 & 1.4 & 1.8 & 3.6 & 2.5 & 2.5 & 2.1 & 1.6 & - \\
\hline iso- $\mathrm{C}_{16: 0}$ & 33.6 & 47.6 & 34.5 & 13.9 & 16.7 & 32.9 & 12.2 & 30.5 & 38.1 \\
\hline iso- $\mathrm{C}_{16: 1} \mathrm{H}$ & - & 5.3 & 1.4 & - & - & - & - & - & 2.1 \\
\hline $\mathrm{C}_{17: 0}$ & 5.5 & - & 2.8 & 2.3 & 13.4 & 16.4 & 17.8 & 2.2 & 3.5 \\
\hline $\mathrm{C}_{17: 0} 10$-methyl & 3.7 & 7.1 & 3.9 & 1.2 & - & 2.1 & 2.8 & 2.7 & 6.0 \\
\hline $\mathrm{C}_{17: 1} \omega 8 c$ & 11.5 & 1.1 & 6.9 & 4.7 & 20.0 & - & 26.2 & 20.9 & 11.9 \\
\hline iso- $\mathrm{C}_{17: 0}$ & 2.1 & 4.5 & 4.4 & 4.9 & 4.1 & 3.3 & 1.5 & 6.6 & 3.9 \\
\hline iso- $\mathrm{C}_{17: 1} \omega 9 c$ & 1.7 & 11.4 & 4.8 & 6.2 & - & - & - & 2.1 & - \\
\hline anteiso- $\mathrm{C}_{17: 0}$ & - & - & 2.4 & 15.7 & 2.2 & 2.0 & - & 2.0 & 5.7 \\
\hline anteiso- $\mathrm{C}_{17: 1} \omega 9 c$ & - & - & - & 1.9 & - & - & - & - & - \\
\hline $\mathrm{C}_{18: 0}$ & - & - & - & 2.1 & 1.5 & 2.7 & 3.9 & - & - \\
\hline $\mathrm{C}_{18: 1} \omega 9 c$ & 2.1 & - & - & 9.0 & 7.6 & 3.9 & 17.5 & 15.8 & 13.3 \\
\hline iso- $\mathrm{C}_{18: 0}$ & 1.2 & - & 2.3 & - & 1.1 & 3.2 & 3.4 & 1.3 & - \\
\hline $\mathrm{C}_{19: 0}$ & - & - & - & - & - & - & 1.9 & - & - \\
\hline Summed feature $3^{\star}$ & 1.6 & - & 3.4 & 1.9 & 2.1 & - & - & - & - \\
\hline Summed feature $6^{*}$ & 2.5 & 1.8 & - & - & 3.7 & - & - & 3.7 & 2.32 \\
\hline Polar lipids $\dagger$ & $\begin{array}{l}\text { DPG, PI, } \\
\text { PE, PL }\end{array}$ & $\begin{array}{c}\text { DPG, PI, } \\
\text { PE, PL, PG }\end{array}$ & $\begin{array}{l}\text { DPG, PI, PE } \\
\text { PL, PG }\end{array}$ & $\begin{array}{l}\text { DPG, PI, PE, } \\
\text { PL, PG }\end{array}$ & $\mathrm{NA}$ & $\mathrm{NA}$ & $\begin{array}{c}\text { DPG, } \\
\text { PI, PG }\end{array}$ & $\begin{array}{l}\text { DPG, PI, } \\
\text { PG }^{d}\end{array}$ & $\begin{array}{l}\text { DPG, PI, } \\
\text { PG }^{e}\end{array}$ \\
\hline DNA G $+\mathrm{C}$ content $(\mathrm{mol} \%) \dagger$ & 70.9 & $68^{a}$ & $69^{a}$ & $73.0^{b}$ & 73 & $\mathrm{NA}$ & $70^{c}$ & $72^{d}$ & $69^{e}$ \\
\hline
\end{tabular}

${ }^{*}$ Summed feature 3 comprises iso- $\mathrm{C}_{15: 0} 2-\mathrm{OH}$ and/or $\mathrm{C}_{16: 1} \omega 7 c$, summed feature 6 comprises $\mathrm{C}_{19: 1} \omega 9 c$ and/or $\mathrm{C}_{19: 1} \omega 11 c$.

$\dagger$ Data from: $a$, Groth et al. (2002); b, Weon et al. (2007); c, Martin et al. (1997); d, Imamura et al. (2000); and e, Yoon et al. (2000). 
showed that $K$. sinensis and $K$. subterranea contained iso$\mathrm{C}_{15: 0}$, iso- $\mathrm{C}_{17: 0}$, iso- $\mathrm{C}_{16: 0}$ and anteiso- $\mathrm{C}_{17: 0}$ as major fatty acids ( $>10 \%)$ on TSB media. However, Weon et al. (2007) showed that $K$. aerolata had iso- $\mathrm{C}_{16: 0}, \mathrm{C}_{17: 1} \omega 8 c$ and iso$\mathrm{C}_{15: 0}$ as the major fatty acids $(>10 \%)$ on R2A media. In this study, we reanalysed the fatty acids for strains of the three Knoellia species together with strain $\mathrm{TL}^{\mathrm{T}}{ }^{\mathrm{o}}$ on $\mathrm{R} 2 \mathrm{~A}$ media and the results were very similar to those reported by Weon et al. (2007).

Therefore, on the basis of the distinctive phenotypic, chemotaxonomic and phylogenetic traits, strain $\mathrm{TL}^{\mathrm{T}}$ represents a novel species in the genus Knoellia, for which the name Knoellia flava sp. nov. is proposed.

\section{Description of Knoellia flava sp. nov.}

Knoellia flava (fla'va. L. fem. adj. flava yellow, referring to colony colour after incubation on R2A at $28{ }^{\circ} \mathrm{C}$ for 3 days).

Cells are Gram-positive, non-motile, non-spore-forming, non-acid-fast, irregular rods $(0.6 \times 1.0-1.9 \mu \mathrm{m})$ and cocci (0.5-1.1 $\mu \mathrm{m}$ diameter). Colonies are yellow, circular, smooth and convex on R2A agar, and light yellow, circular, smooth and convex on R agar. Grows aerobically at $4-37{ }^{\circ} \mathrm{C}$ (optimum growth at $28{ }^{\circ} \mathrm{C}$ ), but not at $0{ }^{\circ} \mathrm{C}$ or $42{ }^{\circ} \mathrm{C}$. Anaerobic growth is not observed. Grows at pH 5-9, with optimum growth at $\mathrm{pH}$ 7.0. In $\mathrm{R}$ medium, tolerates up to $5 \% \mathrm{NaCl}$ (optimum growth at $0 \% \mathrm{NaCl}$ ). Grows on $\mathrm{R}$ agar, R2A agar, LB agar and TSB agar, but not on MacConkey agar. Catalase-positive and oxidase-negative. Tween 80, Tween 20, starch, gelatin, aesculin and casein are hydrolysed, but chitin, carboxymethyl-cellulose, L-tyrosine and urea are not hydrolysed. Positive for the production of $\mathrm{H}_{2} \mathrm{~S}$, nitrate reduction and $\beta$-galactosidase, but negative for indole production, glucose fermentation, and Voges-Proskauer and methyl red tests. A weak reaction is detected for arginine dihydrolase. According to results from API 20NE and API ID 32GN test strips, D-glucose, D-mannose, D-mannitol, maltose, malic acid, sucrose, D-sorbitol, propionic acid, valeric acid, glycogen, salicin, sodium acetate, lactic acid, L-alanine, L-serine, L-histidine, 3-hydroxybutyric acid and Lproline are assimilated, but L-arabinose, $\mathrm{N}$-acetylglucosamine, potassium gluconate, capric acid, adipic acid, trisodium citrate, phenylacetic acid, L-rhamnose, D-ribose, inositol, itaconic acid, suberic acid, sodium malonate, potassium 5-ketogluconate, 3-hydroxybenzoic acid, melibiose, L-fucose, potassium 2-ketogluconate and 4-hydroxybenzoic acid are not assimilated. Alkaline phosphatase, esterase (C4), esterase lipase (C8), leucine arylamidase, valine arylamidase, cystine arylamidase, acid phosphatase, naphthol-AS-BI-phosphohydrolase, $\beta$-galactosidase, $\alpha$-glucosidase and $\beta$-glucosidase activities are detected by the API ZYM system, but not $\alpha$-chymotrypsin, $\alpha$-galactosidase, $\beta$ glucuronidase, $N$-acetyl- $\beta$-glucosaminidase, $\alpha$-mannosidase or $\alpha$-fucosidase. Weak reactions are detected for lipase (C14) and trypsin. Resistant to $(\mu \mathrm{g})$ penicillin (10), trimethoprim (5), ampicillin (10) and nalidixic acid (30). Sensitive to $(\mu \mathrm{g})$ amoxicillin (20), cefotaxime (30), chloramphenicol (30), kanamycin (30), polymyxin B (25), cefoxitin (30), streptomycin (10), erythromycin (15), nitrofurantoin (30), neomycin (30), novobiocin (30) and tobramycin (10). Major cellular fatty acids $(>10 \%)$ are iso- $\mathrm{C}_{16: 0}$, iso- $\mathrm{C}_{15: 0}$ and $\mathrm{C}_{17: 1} \omega 8 c$ on $\mathrm{R} 2 \mathrm{~A}$ medium. The major polar lipids are $\mathrm{PE}$, $\mathrm{PI}$ and DPG. The cell wall peptidoglycan type is meso-DAP. The predominant menaquinone is MK- $8\left(\mathrm{H}_{4}\right)$.

The type strain is $\mathrm{TL}^{\mathrm{T}}$ (=CGMCC $1.10749^{\mathrm{T}}=\mathrm{KCTC}$ $19810^{\mathrm{T}}$ ), isolated from pig manure in Wuhan, central PR China. The DNA $\mathrm{G}+\mathrm{C}$ content of the type strain is $70.9 \mathrm{~mol} \%$.

\section{Acknowledgements}

We are grateful to KCTC and DSMZ for providing $K$. sinensis KCTC $19936^{\mathrm{T}}$, K. subterranea KCTC $19937^{\mathrm{T}}$ and K. aerolata DSM $18566^{\mathrm{T}}$, and Dr Jean Euzéby (École National Vétérinaire) for the etymology of our novel species. This work was supported by the Major International Collaboration Project of National Natural Science Foundation of China (31010103903).

\section{References}

Cowan, S. T. \& Steel, K. J. (1965). Manual for the Identification of Medical Bacteria. London: Cambridge University Press.

Dussault, H. P. (1955). An improved technique for staining red halophilic bacteria. J Bacteriol 70, 484-485.

Felsenstein, J. (1981). Evolutionary trees from DNA sequences: a maximum likelihood approach. J Mol Evol 17, 368-376.

Fitch, W. M. (1971). Toward defining the course of evolution: minimum change for a specific tree topology. Syst Zool 20, 406-416.

Groth, I., Schumann, P., Schütze, B., Augsten, K. \& Stackebrandt, E. (2002). Knoellia sinensis gen. nov., sp. nov. and Knoellia subterranea sp. nov., two novel actinobacteria isolated from a cave. Int J Syst Evol Microbiol 52, 77-84.

Guindon, S., Lethiec, F., Duroux, P. \& Gascuel, O. (2005). PHYML Online-a web server for fast maximum likelihood-based phylogenetic inference. Nucleic Acids Res 33 (Web Server issue), W557-W559.

Huß, V. A. R., Festl, H. \& Schleifer, K. H. (1983). Studies on the spectrophotometric determination of DNA hybridization from renaturation rates. Syst Appl Microbiol 4, 184-192.

Imamura, Y., Ikeda, M., Yoshida, S. \& Kuraishi, H. (2000). Janibacter brevis sp. nov., a new trichloroethylene-degrading bacterium isolated from polluted environments. Int J Syst Evol Microbiol 50, 1899-1903.

Kageyama, A., Takahashi, Y., Yasumoto-Hirose, M., Kasai, H., Shizuri, Y. \& Omura, S. (2007). Janibacter corallicola sp. nov., isolated from coral in Palau. J Gen Appl Microbiol 53, 185-189.

Kämpfer, P., Terenius, O., Lindh, J. M. \& Faye, I. (2006). Janibacter anophelis sp. nov., isolated from the midgut of Anopheles arabiensis. Int J Syst Evol Microbiol 56, 389-392.

Kroppenstedt, R. M. (1985). Fatty acid and menaquinone analysis of actinomycetes and related organisms. In Chemical Methods in Bacterial Systematics (Society for Applied Bacteriology Technical Series vol. 20), pp. 173-199. Edited by M. Goodfellow \& D. E. Minnikin. New York: Academic Press.

Lang, E., Kroppenstedt, R. M., Swiderski, J., Schumann, P., Ludwig, W., Schmid, A. \& Weiss, N. (2003). Emended description of Janibacter terrae, including ten dibenzofuran-degrading strains and Janibacter 
brevis as its later heterotypic synonym. Int J Syst Evol Microbiol 53, 1999-2005.

Lányí, B. (1987). Classical and rapid identification methods for medically important bacteria. Methods Microbiol 19, 1-67.

Lee, S. D. (2006). Phycicoccus jejuensis gen. nov., sp. nov., an actinomycete isolated from seaweed. Int J Syst Evol Microbiol 56, 2369-2373.

Martin, K., Schumann, P., Rainey, F. A., Schuetze, B. \& Groth, I. (1997). Janibacter limosus gen. nov., sp. nov., a new actinomycete with meso-diaminopimelic acid in the cell wall. Int J Syst Bacteriol 47, 529534.

Mesbah, M., Premachandran, U. \& Whitman, W. B. (1989). Precise measurement of the $\mathrm{G}+\mathrm{C}$ content of deoxyribonucleic acid by highperformance liquid chromatography. Int J Syst Bacteriol 39, 159-167.

Ryu, E. (1938). On the Gram-differentiation of bacteria by the simplest method. J Jpn Soc Vet Sci 17, 58-63.

Saitou, N. \& Nei, M. (1987). The neighbor-joining method: a new method for reconstructing phylogenetic trees. Mol Biol Evol 4, 406425.

Sasser, M. (1990). Identification of bacteria by gas chromatography of cellular fatty acids, MIDI Technical Note 101. Newark, DE: MIDI Inc.

Schleifer, K. H. \& Kandler, O. (1972). Peptidoglycan types of bacterial cell walls and their taxonomic implications. Bacteriol Rev 36, 407-477.

Schumann, P., Kämpfer, P., Busse, H.-J., Evtushenko, L. I. \& Subcommittee on the Taxonomy of the Suborder Micrococcineae of the International Committee on Systematics of Prokaryotes (2009). Proposed minimal standards for describing new genera and species of the suborder Micrococcineae. Int J Syst Evol Microbiol 59, 1823-1849.

Shivaji, S., Chaturvedi, P., Begum, Z., Pindi, P. K., Manorama, R., Padmanaban, D. A., Shouche, Y. S., Pawar, S., Vaishampayan, P. \& other authors (2009). Janibacter hoylei sp. nov., Bacillus isronensis sp. nov. and Bacillus aryabhattai sp. nov., isolated from cryotubes used for collecting air from the upper atmosphere. Int J Syst Evol Microbiol 59, 2977-2986.

Smibert, R. M. \& Krieg, N. R. (1994). Phenotypic characterization. In Methods for General and Molecular Bacteriology, pp. 607-654. Edited by P. Gerhardt, R. G. E. Murray, W. A. Wood \& N. R. Krieg. Washington, DC: American Society for Microbiology.

Stackebrandt, E. \& Goebel, B. M. (1994). Taxonomic note: a place for DNA-DNA reassociation and $16 \mathrm{~S}$ rRNA sequence analysis in the present species definition in bacteriology. Int J Syst Bacteriol 44, 846849.

Stackebrandt, E. \& Schumann, P. (2000). Description of Bogoriellaceae fam. nov., Dermacoccaceae fam. nov., Rarobacteraceae fam. nov. and
Sanguibacteraceae fam. nov. and emendation of some families of the suborder Micrococcineae. Int J Syst Evol Microbiol 50, 1279-1285.

Stackebrandt, E., Rainey, F. A. \& Ward-Rainey, N. L. (1997). Proposal for a new hierarchic classification system, Actinobacteria classis nov. Int J Syst Bacteriol 47, 479-491.

Tamura, K., Dudley, J., Nei, M. \& Kumar, S. (2007). MEgA4: Molecular evolutionary genetics analysis (MEGA) software version 4.0. Mol Biol Evol 24, 1596-1599.

Thompson, J. D., Higgins, D. G. \& Gibson, T. J. (1994). CLUSTAL W: improving the sensitivity of progressive multiple sequence alignment through sequence weighting, position-specific gap penalties and weight matrix choice. Nucleic Acids Res 22, 4673-4680.

Tindall, B. J. (1990). A comparative study of the lipid composition of Halobacterium saccharovorum from various sources. Syst Appl Microbiol 13, 128-130.

Ventosa, A., Marquez, M. C., Kocur, M. \& Tindall, B. J. (1993). Comparative study of "Micrococcus sp." strains CCM 168 and CCM 1405 and members of the genus Salinicoccus. Int J Syst Bacteriol 43, 245-248.

Wang, Z. G., Wang, Y. X., Liu, J. H., Chen, Y. G., Zhang, X. X., Wen, M. L., Xu, L. H., Peng, Q. \& Cui, X. L. (2009). Fodinibacter luteus gen. nov., sp. nov., an actinobacterium isolated from a salt mine. Int J Syst Evol Microbiol 59, 2185-2190.

Weon, H. Y., Kim, B. Y., Schumann, P., Kroppenstedt, R. M., Noh, H. J., Park, C. W. \& Kwon, S. W. (2007). Knoellia aerolata sp. nov., isolated from an air sample in Korea. Int J Syst Evol Microbiol 57, 2861-2864.

Xie, C. H. \& Yokota, A. (2003). Phylogenetic analyses of Lampropedia hyalina based on the 16S rRNA gene sequence. J Gen Appl Microbiol 49, 345-349.

Yoon, J.-H., Lee, K.-C., Kang, S.-S., Kho, Y. H., Kang, K. H. \& Park, Y.-H. (2000). Janibacter terrae sp. nov., a bacterium isolated from soil around a wastewater treatment plant. Int J Syst Evol Microbiol 50, 1821-1827.

Yoon, J.-H., Lee, H. B., Yeo, S.-H. \& Choi, J.-E. (2004). Janibacter melonis sp. nov., isolated from abnormally spoiled oriental melon in Korea. Int J Syst Evol Microbiol 54, 1975-1980.

Zhi, X.-Y., Li, W.-J. \& Stackebrandt, E. (2009). An update of the structure and 16S rRNA gene sequence-based definition of higher ranks of the class Actinobacteria, with the proposal of two new suborders and four new families and emended descriptions of the existing higher taxa. Int J Syst Evol Microbiol 59, 589-608.

Zou, Z. \& Wang, G. (2010). Kushneria sinocarnis sp. nov., a moderately halophilic bacterium isolated from a Chinese traditional cured meat. Int J Syst Evol Microbiol 60, 1881-1886. 